Exclusion and reappropriation: Experiences of contemporary enclosure among children in three East Anglian schools

Accepted for Environment and Planning D: Society and Space

Richard DG Irvine

Division of Social Anthropology, University of Cambridge, UK

Elsa Lee

Faculty of Education, University of Cambridge, UK

Miranda Strubel

Department of Social Sciences, Oxford Brookes University, UK

Barbara Bodenhorn

Division of Social Anthropology, University of Cambridge, UK

\begin{abstract}
Transformations of the landscapes which children inhabit have significant impacts on their lives; yet, due to the limited economic visibility of children's relationships with place, they have little stake in those transformations. Their experience, therefore, illustrates in an acute way the experience of contemporary enclosure as a mode of subordination. Following fieldwork in three primary schools in South Cambridgeshire, UK, we offer an ethnographic account of children's experiences of socio-spatial exclusion. Yet, we suggest that such exclusion is by no means an end-point in children's relationships with place. Challenging assumptions that children are disconnected from nature, we argue that through play and imaginative exploration of their environments, children find ways to rebuild relationships with places from which they find themselves excluded.
\end{abstract}




\section{Exclusion and reappropriation: experiences of contemporary enclosure among children in three East Anglian schools}

"We don't go there as much"; "I think we're not allowed." These words, spoken by schoolchildren about a once-important place of play, are boundary markers in many children's experience of their environment. They point to an awareness of the everyday impacts of land use change, and a recognition of the processes of spatial exclusion that shape their lives. However, exclusion is not the end of this story: through our research in East Anglia, UK, we have found that children are often active in finding ways to reappropriate their environments, and it is this process that we want to draw attention to here.

Recent work on children's geographies has drawn attention to restrictions on children's movements and their experiences of spatial exclusion. Karsten (2005: 287), writing about Amsterdam, argues that "public space has been transformed from a space that belongs to children (child space) into one meant for adults and accompanied children only", while Woolley (2006) in the context of urban space in England suggests that what appears to be 'open space' is often not experienced as 'open' in the lives of children, who find themselves routinely excluded and moved on from location to location by security guards and others. (See also Veitch et al. (2007) on restrictions on the use of public open spaces in Victoria, Australia.) Similarly, in the context of rural Hampshire, UK, Giddings and Yarwood (2005: 109) state that "the sense of 'open space' around the village is contradicted by its restricted access"; land is fenced off with very few spaces accessible for children to 'explore', and those public spaces that do exist tend to be adult centred. There is a stark disjunction between perceptions of the rural 'good life' and this reality of exclusion (Matthews et al. 2000), with frequent conflicts over who is allowed to be in a particular space (Tucker and Matthews 2001).

In this paper, we suggest that it might be productive to view such exclusions as experiences of enclosure. We recognise that some may view it as provocative to draw a 
connection between children's experiences today and a historic language of enclosure emerging from the dramatic restrictions placed on the use of land as it was brought into private ownership, particularly, from the $16^{\text {th }}$ century onwards (see Thrisk 1984; Neeson 1993; Williamson et al. 2013). In the contemporary context, enclosure may seem more readily applicable to displacement caused by large-scale land acquisitions in the 'global south' (White et al. 2012). Indeed, our usage may seem especially provocative given that, as we will see, we are discussing the lives of children who in many cases are growing up within relatively affluent, middle-class, families. Nevertheless, we believe this is an important provocation. We are not seeking to dilute the concept of enclosure or to distract from its effects elsewhere in the world; rather, we are trying to show the pervasive nature of the logic of enclosure - even within apparently affluent and already-enclosed areas - as it shapes the physical geography of children's lives, and as children attempt to negotiate it. We suggest that it is important to think about the role of enclosure in children's lives for (at least) three reasons.

Firstly, taking our cue from accounts of the severe restrictions of movement and experience of children in the wake of historic enclosures (Humphries 1990), we suggest that children (due to their economic peripherality) are particularly vulnerable to the forms of spatial exclusion characterised by enclosure. Following Vasudevan et al. (2008) in recognising enclosure as a mode of subordination, we see the subordinating experiences of children in their interactions with the land where they live as particularly important in showing us the exclusive character of land-use changes.

Secondly, we believe it is important to recognise enclosure as an ongoing, and not simply an historic phenomenon. As Glassman (2006) has argued, in contrast to earlier Marxist understandings which saw enclosure as a single historical phase of capitalist development, there is a growing recognition that acts of enclosure are recurrent, and that new spaces for accumulation and exclusion are sought even within those spaces that, historically, may already 
have been 'enclosed'. We see, for example, the 'gating' of cities (Low 2001), or ongoing processes of "accumulation by dispossession" (Harvey 2003) such as the privitisation of resources previously held in government ownership, or the accumulation of family farms by large scale agribusinesses (Harvey 2003: 146). In particular, in the UK rural context, it is important to be attentive to new restrictions and exclusions associated with agricultural industrialisation (North 1998) and the ongoing accumulation of smaller farms by large-scale farming businesses; commodification associated with tourism (Perkins 2006; Crouch 2006); and rural housing development, particularly in the wake of the presumption in favour of sustainable development within the National Planning Policy Framework from the Department for Communities and Local Government (2012). As we shall illustrate, children's experiences draw our attention in a vivid way to these ongoing forms of enclosure within already-enclosed areas.

Thirdly, following Hodkinson (2012: 504) in drawing attention to what he terms the "physical geography of enclosure", and in his argument that the restriction of movement was not simply a consequence but the very essence of enclosure, we see it as important to show the role of spatial exclusions in shaping a particular subjectification through which people are "encaptured" within the logic of private ownership and commodification (Hodkinson 2012: 309). Kraftl (2014) in the context of new housing developments in the South Midlands, UK, points to children's expectations that they have to move themselves on and their acceptance of claims that land where they are playing is 'private property'. This, we suggest, is an illustration of the "capitalist subjectification" that Hodkinson sees as key to the process of enclosure, and we therefore use the language of enclosure to draw attention to the ways in which children, through the curtailment of their own relationships with place, are led to accept a particular understanding of their geography as a restricted one, and a particular view of the inevitability of a particular economic rationality of exclusive and privatised land use. 
Hodkinson's emphasis on the spatiality of enclosure raises interesting questions when read in conjunction with recent work that places materiality at the heart of children's geographies. Recognising a need to "escape the constraints of bio-social dualism" (Ryan 2011: 443), Rautio (2013: 402) asks us to "consider whether bridging the nature-culture divide can be attempted by exploring practices through which children themselves seem to do this". Such an approach brings into view the significance of banal embodied encounters with the world around in which thought and action are entwined with particular spaces and their tangible materiality - to draw on examples from Horton and Kraftl (2006), notches for climbing up trees; boundaries of the cricket pitch; the familiar feel of certain grass underfoot; or, as highlighted by Christensen et al. (2015), the significance children place on finding a new shortcut. The accounts of children's relationships with their environment here reflect this recognition of interdependence: children work, think, and exist, with and through the material world. This emphasis on what Rautio (2014) calls the "mingling" between children and material enables a shift in discussion "from knowing about the world towards knowing with the world" (2014: 462). We would contest that enclosure disrupts this mingling precisely by restricting movement, restricting everyday banal material encounters, and therefore placing children in a position where they are restricted in what they can 'know with'. The subjectification to which Hodkinson (2012) draws our attention, and which follows from restriction of movement, is therefore one which might be thought to reconfigure this 'mingling' between child and place, allowing for the possibility of a relationship only within the context of an understanding of land as exclusive.

Yet central to our argument in this paper is that while children experience spatial exclusion, they are active and creative in seeking ways to re-establish relationships with those places from which they are excluded. Indeed, we would suggest that a focus on children is of particular interest in revealing repertoires of response to enclosure. As Christensen et al. 
(2015) argue in the context of suburban Copenhagen, contestation is a central feature in how children experience place: signs that forbid play are a source of exclusion, but also can be a source of place-making as children make places their own precisely by challenging these roles. Jeffrey et al. (2012) refer to a 'dialectic' of enclosure-commons through which acts of enclosure are thought of in conjunction with the emergence of "new imaginaries, possibilities and associations" existing in creative tension with that enclosure. The study of children's relationship with enclosure therefore brings to the fore not only restrictions, but also creative means of reappropriation, particularly by way of play and narrative imagination: 'minglings' (to borrow again from Rautio) in which children improvise ways of working, thinking, and existing, with and through an enclosed material world.

Here, we draw in particular on the work of Colin Ward $(1978 ; 1988)$, which continues to provide ample theoretical and methodological stimulation for thinking about the ways that children interact with their environment (Harris et al. 2000; Goodway 2006; Worpole 2014). In particular, we suggest that Ward documents vividly the ongoing development of enclosure in contexts that might be thought of as 'already enclosed'; as Philo (1992) states, a central dynamic in the changing rural world Ward describes is the growth of farms via accumulation and an "increasing hegemony of capitalist property relations that sustain an individualistic ideology of private property manifested in 'trespassers will be prosecuted' notices" (Philo 1992: 197). Drawing on his architectural training, and later on his role as Education Officer of the Town and Country Planning Association, Ward's attention to the historic dynamics of planning, development, and change and how they shape the basis of children's social life is combined with vivid insights into the everyday ways in which children adapt the imposed environment. Ward was someone with direct experience of how planning reshapes the lived environment, but also how people take and appropriate in their own lives that which has been planned: the constrictions of 'tidying up' and creating ordered spaces - and children's capacity 
to reorder for their own purposes (Cloke and Jones 2005). Taking inspiration from this, our article recognises the effects of what Ward described as the "land-use conflict between children and adults" (Ward 1978: 96) while at the same time trying to convey the texture of the improvisational and creative ways in which children inhabit their environment.

In the next section of the paper, we outline the context of our fieldwork, before going on to consider the material encounters which shape children's experience of their place. We then turn to the specific experience of spatial exclusion in children's lives, before discussing the ways in which children attempt to reconnect with and reappropriate those places from which they find themselves excluded. Finally, we return to the literature exploring historical and contemporary experiences of enclosure, and reflect on the particular significance of children's lives for our understanding of these dynamics.

\section{Place}

The fieldwork upon which this article draws took place in three Primary schools in South Cambridgeshire, working with children predominantly aged between 7 and 11 (though in each of the schools we were also asked to organise additional activities for children of a younger age) between January and July 2014.

In each school, our research involved the development of activities through which children could investigate the locality of their school and reflect on changes within their environment. This process was a collaborative one in which we actively sought to include children and teacher's participation in the design of research activities. Our experience here resonates with Cahill (2007: 300), who remarks of participatory research that "precisely because it was collaborative I could not plan and structure the process ahead of schedule and the research evolved in a slightly messy, organic way". The advantage of such an approach was that it allowed for the development of location-specific 'contact zones', drawing together 
not only the 'researchers' and 'research participants', but also the particularities and materialities of place (Askins and Pain 2011). Of course, it is important to note the difficulties of balancing the different needs and goals of participants within such a collaboration. As Skelton (2008) has highlighted, even as we recognise children as competent social actors, their full participation is often restricted by the institutional setting of the school setting limits on the children's capacity to shape the research agenda, in addition to which there can be a distance between what is 'good for the University' and what is important to the children. So the teacher's emphasis on how our activities might help extend the curriculum, and our emphasis on gathering reflections on environmental change might easily overshadow the children's interests. Nevertheless, through leaving the nature of investigations of place open and giving children a role in their development, we hope that we have given sufficient space for them to relate their own experiences and areas of involvement and interest.

The initial phase of research took the form of planning sessions during October and November of 2013, working with teachers in each of the schools to work out how best to fit our research with ongoing work in the classroom. All schools in our research had clear protocols for including children in research, especially with regard to recording and anonymity. We were open about our work, explaining in class what our plans were, and that the work we were doing would be included in research publications, reiterating our status as researchers evident during each occasion where we interacted with the children. Children were asked for their consent and given the opportunity to opt-out at the outset; additionally, information was sent home to parents again seeking consent and offering the opportunity to opt out. Besides the schools' protocols and the other measures outlined above, our approach was to ensure that we constantly evaluated and re-evaluated the children's engagement with the project. Hence we continuously sought to (re)determine whether a child was happy to be involved, and we were committed to offering any child that showed discomfort the 
opportunity to withdraw. However, no such discomfort was observed and so the data from all children remained accessible to the researchers. We have remained committed to giving children an active role in shaping the direction of our research, and in September 2014 children from each school were invited to participate in a conference about the research at our institution.

Following these initial planning sessions with teachers, in each school we then spent between 1 and 2 weeks working directly with the children for the majority of the school day, with additional meetings after the activities for purposes of follow-up data gathering. During our first meetings with the children we identified places and issues of environmental interest in the local area, and then worked to facilitate creative investigations of those places that would prompt reflections on processes of change and other issues at stake for the children. In this sense, we have attempted to take a participatory approach (Thomas and O'Kane 1998; Alderson 2001; Waller and Bitou 2011; Groundwater-Smith et al. 2015), giving children the opportunity to shape the direction of the research by defining the places and topics of interest. Then, recognising the potential of creative work within participatory research (Veale 2004), we organised specific activities with the aim of generating extended reflections, each organised on the basis of their relevance to the places and topics identified. The activities (one per class) decided upon were: storywriting and storytelling performances about places of local interest; storybook illustration of folktales responding to the local environment; observation of small mammal activity in a local river followed by creative writing about the river environment; creation of artworks in a local woodland. Each of these activities was supported by a relevant practitioner who we had invited to participate in the project (e.g. artist, storyteller, ecologist, etc.) Here, we draw on the methodological approach of ethnographic conceptualism (Ssorin-Chaikov 2013), generating commentary, response, and reflection by 
means of particular creative interventions, taking as a site of ethnographic reflection the ways in which participants reflect on and through this creative work.

To say something further of the setting: research took place in three schools located in villages amongst the chalk hills of South Cambridgeshire. The communities are rural, although a high proportion of the population commutes from the villages to nearby urban settlements; furthermore, the villages (in common with many in the region; see Strathern (1981); Ahmed and Mynors (1994); Jenkins (1999: 45-60)) have been subject to a demographic transformation through the arrival of urban settlers over the past half a century. Consequently, while the children may have been raised locally and therefore had lifelong experience of rural living, in many cases the same could not be said of their parents. Overall, the participating schools are similar in terms of their intake, who are predominantly (though not exclusively) White British, with below average numbers of special educational needs pupils $(0.5 \%$ in the project schools compared to a national average of $2.8 \%)$, and below the average numbers in receipt of pupil premium or free school meals $(12.5 \%$ in the project schools compared to a national average of $15.2 \%$, indicating that the populations under consideration are relatively, if not exceptionally, affluent.

In terms of the children's sense of place, a central observation was that geology played a key role in children's lives, and interactions with the chalky landscape figured significantly in their imaginations. Chalk was a visible and tangible presence, and more than this, a factor in everyday life. Several children in both Orwell and Barrington remarked upon the vivid white exposures of chalk "You see it all the time when you're going along the road"; and for some the lived connection was domestic: as one child in Barrington remarked, "my shed's made from the pits", sourcing the stone used to make a building in the farm where they lived from the chalk pits in the village (discussed below). 
The presence of chalk therefore manifested itself in a number of ways. Firstly, chalk figured in the built environment. As one child in Orwell asked, "Isn't our church built of it?"; or in the words of another child in Barrington "they used it to make my windmill". Churches and other buildings in the villages (including in some cases, such as the converted windmill referred to above, the houses in which children lived) were built from clunch, a hardened chalk of the Cretaceous period chemically altered by the cementing of the silica and thus suitable for cutting and using as a building material. In thinking about the processes of formation and extraction of this stone, children encounter very different ways of thinking about timescale, as witnessed in the juxtaposition of a display about tectonic plates and a photograph of the village church in one of the classrooms. In an important sense, here we see encounters with deep time becoming part of everyday lived experience (Irvine 2014).

Secondly, chalk was engrained in local politics and economics. Barrington, one of the villages where we worked, had until recently been physically and economically dominated by a cement works; "They made the chalk from the fossils; where the fossils were underground, that's where the chalk was, and they dug it away", with the chimney of the cement works (or tower as the children called it) "like a beacon", announcing where the village was. The closure of these works in 2008 has led to a great deal of uncertainty as to how the land will be used. After a fieldtrip to the mothballed works one of the classes at the school (consisting of children aged 7-9) came to investigate the future of the site, setting out passionate cases for a range of future uses (a theme to which we shall return).

Thirdly, and perhaps most importantly, chalk was a key presence in children's places of play. This was most obvious in the enthusiastic and animated discussion of the clunch pit in the village of Orwell (that is, the site where clunch had been quarried over generations, now no longer used for this purpose) - indeed, no discussion at the school over the course of our fieldwork generated as much excitement as the opportunity to describe the pit. "It's chalky"; 
"damp"; "nothing at all is flat"; "you know you get quarries, it's like hills all the way around, then there's the hole"; "an ogre lives in the hole"; "there's a cave - it's hard to get in, you have to climb to the top"; "when it snows there's a really good tobogganing run".

Unsurprisingly, when children chose sites to do fieldwork and make observations over the half term holiday, the majority chose to do this work in the clunch pit, as elaborated below.

In considering how meaning is generated anew, it is important to recognise the material properties of the landscape, noting not only the temporal richness of the land - the local history of building materials, or the discovery of fossils in the chalk as a window onto deep time - but also an improvisational richness. Armstrong (1980), in his observations of classroom life in a primary school in Leicestershire, remarks at length on children's responsiveness to materials, while Katz (2004: 105) describes the way children in rural Sudan used mud and other materials at hand to build houses: "with the rains came clayey mud, and with the mud came opportunity". Similarly Jean Briggs, writing about experimentation as learning among the Canadian Inuit, as well as Barbara Bodenhorn working among the Alaskan Inupiat, describe children coming to learn from the properties of materials in a handson, experimental, way, seeing "materials for use" (Briggs 1991: 272; Bodenhorn 1997). The question to be asked of landscape here is 'how do we use this?', and thus play is of key importance, whether this means grabbing loose bits of chalk and scrawling away with them on picnic tables, or the titillatingly dangerous descent by BMX down a quarried slope.

This resonates with the recent attention to the materiality of children's geographies; Rautio (2013), for example, describes not only children's openness to their surroundings through touch, but also the 'vibrancy' of stones which seem to involve themselves in play. Children are "conversant and open to be played with by the things around them. This is how things are able to invite children to play" (Rautio 2014: 648). This recognition of how we know with the world leads Kraftl (2014) to draw our attention to place making through play 
(such den building and Star Wars in the woods) as well as the development of intimate local knowledges through "just walking round" (2014: 287).

Indeed, the children were at their most effusive when describing places of play, and it was these places that took centre stage as we developed activities which gave the children scope to reflect. For example, the site known locally as "Little Rivers" was important to the children in Barrington school: "We like to go swimming"; "and sometimes you nearly drown"; "sometimes if you don't want to jump in you go to the shop and get a sweet and sit there"; "you can sit on the bank and sunbathe"; "you can take your nets and try and catch crayfish"; "I've used my shoes to catch crayfish" - and it was here that we took the oldest class in the school to make observations, setting out feeding stations and camera traps to find evidence of water voles and other species living there, and also encouraging them to write poetry about the site, getting them to reflect on how the area might have changed or be changing.

Significantly, these engagements revealed a deep experience-led connection with the local environment. Inherent in theories such as the highly influential "nature deficit disorder" (Louv 2005) is a presumption that children, tangled up in a world of parental fears and consumer electronics, are increasingly disconnected from their 'natural' environment; "they do not know how to describe what they miss because they have never had it" (Griffiths 2013: 12). We feel it is important to push on from these accounts in two ways. Firstly, what we are arguing within this paper is that children's own sense of exclusion from their environment may not emerge from a state of disconnection, but rather from a vivid lived relationship with their surroundings - a relationship that they perceive to be under threat through processes of exclusion which we describe below. Secondly, we do not treat exclusion as the end-point of children's relationships, but instead we want to point to the ongoing processes by which children try and make places that they have been excluded from theirs again. 


\section{Exclusion}

If places of play are 'children's places', as Olwig and Gulløv (2003) remind us it is important to remember that they are very rarely children's places in an uncontested way. Indeed, over the course of our research, it became clear that children experienced exclusion from the environment around them in a number of ways.

Development of land was a key theme in reflections about the future: children seemed to envision a near-inevitable future in which places that were familiar and important to them would be built upon and otherwise transformed. That the children were astute observers of the trends of development shaping the countryside was almost immediately apparent to us during fieldwork; for example, envisioning the future of a building in the local area (the clubhouse at Whaddon Golf Club), one 10 year old boy declared "it will probably turn into a restaurant like a Hungry Horse or a Harvester like the one in Baldock", the spread of these ubiquitous "chain pub' franchises from one village to the next having been well observed over the past few years. But probably the principal force that the children saw at work transforming their environment was the building of new roads and houses - a reflection of new forms of enclosure in already-enclosed land as a consequence of the private development of land for housing in the wake of the 'presumption in favour of sustainable development' within the National Planning Policy Framework from the Department for Communities and Local Government (2012).

At Petersfield School in the village of Orwell, this awareness of development came through clearly in children's project work exploring the clunch pit. When writing about the future of this important place of play, they imagined construction work. To quote one 10 year old boy: "In one hundred years time, I think that the Clunch Pit won't be there. I think that it will be replaced with some houses or a building site." Similarly, one 11 year old girl imagined from a first person perspective how the site might have changed through generational time; 
first describing the pit as though she was watching clunch quarrying in past generations, then describing the scene as she might look on it returning in 50 years: "I can hear the whirring of the wind turbines roar in the fields. Houses are lined up in rows, all identical and plain. All I can see is houses and roads. I can picture the scene as just fields but those memories are faded."

At Barrington, particular anxieties about the future of the cement works came across in the discussions of the children (aged between 7 and 9) visiting that site. "When I think of our village it's a safe place, but people move in [on the cement works site] and I get scared"; "If we had lots and lots more houses it would make it a town." Here, it is important to recognise that children are voicing concerns that they might have heard from adults, including their parents (the deep roots of conflict over housing development in the region are well described by Brindley et al. 1996: 22-40), and we should certainly pay attention to the role of adult talk in framing children's concerns (as implied, for example, when children are picking up on prejudices about immigration in these discussions: "What if Hungarians come and live there?") Nevertheless, it would be a gross mistake to sideline children's perspectives as mere proxies for their parents' points of view.

That children had their own particular perspective on development became apparent through reflections on the future of places of play such as Little Rivers at Barrington, places that a number of the children said that they knew well but that their parents did not know about. The children were asked to imagine and represent in pictures and/or words what they thought the site would have been like 50 years in the past and would be like 50 years in the future. Some of them suggested that there were no changes and that the site would remain the same. However, the vast majority envisaged a future in which the site had been built upon: "no more nature - houses + roads"; "I think on most of the fields houses. There will be less crayfish"; "Less trees - houses or roads"; "Nothing there. House built on top of field. Horses 
somewhere else." These children seem to present a teleology of progress as exclusion, with a sense of the inevitability of the loss of places of play coupled with a recognition of the ecological impacts of that loss.

Related to this, some of the children spoke of changes to their surroundings in ways that implied a commodification of the landscape (a theme highlighted by Smith and Barker (2001) in their account of children's experience of play). Considering again descriptions of the future of the Little Rivers site, one 9 year old boy described a café, picnic area, and BMX track (elements which, in the other class, had also figured in the younger children's ideas for what could be done with the cement works site), while a 10 year old girl saw an even more explicitly commodified leisure space: "Theme park. Flowers. Pay to get in." Here, places of play come to resemble well-known leisure and tourist destinations. In Bassingbourn School, when the storyteller we ran workshops with asked children to "take a trip in their minds", almost all chose to take a trip to such commercial destinations, such as Dinseyworld, Legoland, or Cadbury World. One may indeed be tempted to treat this as evidence of "nature deficit disorder' (Louv 2005), a deprivation of real-world environments to imagine and explore. However, when considered in relation to children's wider visions of the future of their own surroundings we see that this apparent 'disconnection' needs to be understood in the context of a process of perceived exclusion: a sense of the future in which play has become increasingly enclosed.

Central to our use of enclosure here is a sense that what we are seeing in children's lives is not only a sense of spatial exclusion and the restriction of movement, but also an acceptance of the inevitability of that exclusion and restriction. As Hodkinson (2012) has argued, such an acceptance is itself a crucial part of the process of enclosure; a form of subjectification in which one learns to accept that a relationship with place occurs only within a framework of private ownership and economic utility. (To draw on a related example from 
Kraftl (2014: 285-286), consider also the way in which children in the context of a South

Midlands housing development were told to leave places where they play on the grounds that the land was 'private land' - even though there was no evidence for such a claim - and how they develop a sense that they have to move themselves on.) Given such subjectification, it is not surprising that children would see a future in which play is something which they do as customers on land which is, fundamentally, not theirs.

An additional force of exclusion emerges from the demarcation of specific conservation land; as spaces become marked out and managed 'for nature', children find themselves increasingly unwelcome. Mindful of their own play at the Orwell clunch pit, children at Petersfield School reacted angrily when someone in the class said that there were signs that restricted play for conservation reasons at a clunchpit in the nearby village of Harlton: "it's terrible"; "atrocious"; "[signs like that] should be illegal". (Reflecting this sense that play was being eliminated on these sites, in one 10 year old girl's vision of the future of the Orwell clunch pit was a sign marked "no sledging".) What was being challenged here was a "conservation model that excludes people" (Colchester 1994: 16), a pattern which Marcus Colchester describes at length in showing how the interests of indigenous people come to be sidelined in policies of stewardship. Here, conservation becomes a form of enclosure which has disproportionate impacts on those who are marginal to processes of governance (in Colchester's analysis, indigenous people; in our present analysis, children). In such a configuration 'nature' comes to be abstracted from human life even in the very process of conserving it for the good of humankind.

The woodland behind Barrington school, separated from the playground by only a narrow ditch, provided a particularly close-at-hand example of this form of exclusion. Alongside Little Rivers, this had been identified as another important place of play. As one girl in the oldest class at the school explained, "when it's hot we go much more to the river, 
when it's cooler we go to the woods"; but as soon as she had said this, other girls in the class added "we don't go there as much"; "because it's sort of a nature reserve now"; "I think we're not allowed." These woods were on land that had previously been owned by the company that operated the cement works. In 2013 that land - freshly dubbed "Queen Elizabeth II woods" was given to the village for community use, and has since been managed by the parish council, who have done extensive work in order to make it both a nature conservation site and a public amenity. This work, however, has transformed much of the character that made the woods a space of play for the children. In particular, we were told by children throughout the school that by clearing undergrowth and cutting back trees those who maintained the woods had made it far less of an attractive place for them to go. Moreover, recent work marking a path through the woods and blocking some entrance ways - including the removal of a fallen $\log$ that children used to access the woods from the school playground - had given the impression to at least some of the children that they were being discouraged from going there to play. It is worth noting that in Orwell village similar work to turn a woodland area known as Chapel Orchard into a 'green space for nature' was also deemed by some of the children to have rendered the space "boring", although the perception of exclusion there was less pronounced.

The children's sense of place, therefore, seemed to be challenged by two simultaneous forms of enclosure: the designation of spaces for development and of spaces for nature. In such a perception of the changing landscape 'places for nature' appear to be held apart from 'places for humans', and children find limited scope for themselves within either of these designations.

\section{Reappropriation}

Yet children are not passive recipients of a changing environment that is beyond their control. What is striking are the ways that children attempt to reconnect with those places where they 
find themselves excluded. Change is felt as a tangible and, in many respects, inevitable process, yet in the present the children are able to express their own sense of place in the face of such transformations, making it 'theirs' again - even if such attempts are undermined by adults. Katz (2004: 245-246), in her work in rural Sudan, recounts ways in which people "recover and reconnect to landscapes", and while she recognises that these do not necessarily halt the trajectory of the problems that necessitated these acts in the first place, she stresses that "they offer the possibility of fostering something beyond recuperation".

Play is key to this process of re-appropriation. As Colin Ward $(1978 ; 1988)$ has described in great detail, play involves children adapting the imposed environment for their own purposes, and they are resourceful in finding scope for exploration and excitement in places where adults might fail to see such potential, even as the "land-use conflict between children and adults" (Ward 1978: 96), as outlined above, greatly restricts those opportunities. To return to the example of Barrington schoolchildren's play at Little Rivers, as they explained to us, "We make bridges"; "There's a log leading up to the tree, I like to climb on it and get down, and there's the log swing"; "There's lots of wet mud - we like to have mud fights.” As Ward (1988: 103) notes, water and its possibilities for swimming, fishing, and playing in the mud, often adds "an extra touch of magic to a play area", and this relationship with the river allowed room for social gathering as well as personal reflection: "When you're by yourself it can feel peaceful but when you're with a group you're having fun and listening to music." What is significant here is that through their play, children developed a familiarity with particular places - perhaps even an expertise - that their parents and teachers did not necessarily share. Indeed, some teachers in the school were surprised at how familiar children were with the Little Rivers site, having previously considered it an environment that the children would not have been aware of. This accords with the argument of Barratt and Barratt Hacking (2008: 291), developed in a UK urban setting, that "the extent of children's local 
knowledge and attachment is current unknown by adults". Crucially, this knowledge emerges through what Rautio (2014) has described as the 'mingling' of children and material; and it does so in the face of restrictions on movement and access that limit such 'minglings'.

This sense of Little Rivers being a place for play, and a place where the children had competences of their own, spilled over into the class trip there in spite of the pedagogical framing of the visit. Some of the children, having been there after school the day before, told us that they had seen our work to set things up there for the fieldtrip when we had been checking on the feeding stations; in a sense, reminding us that they were one step ahead of us. They may not have had a complete picture of what species lived there (though they were interested to find out more about this, so long as it involved moving and observing rather than just standing and listening), but they were quick to show us that they knew the space well indeed, better than us. The chatter surrounding the trip was as much about their own past adventures there as it was about what we were doing at the time. During a minibeast hunt that we had planned, a group of the children climbed a fence to try and chat with a man fishing on the river, asking him what he had caught, telling him about their own catches when fishing there, and so on.

Even those elements of the class trip that seemed to reinforce a distance between the children and their environment, such as the requirement for purposes of health and safety that children wear rubber gloves and use hand sanitiser when working with the feeding stations, were ripe for turning into a game. The children tried their hardest to see how many squirts of hand sanitizer they could get from this process, approaching their teacher or one of the project team repeatedly and asking in the manner of Oliver Twist, "Pleeease could I have some more?" This quickly escalated into a competition: "that's my seventh bit of hand soap"; "I've had eight". A couple of the children went in search of litter they could handle in order to 
justify getting more hand sanitizer, chanting "We're going on a litter hunt, we're going on a litter hunt, a tissue, a tissue, we all jump up!”

Here, the anthropological challenge is to discover what we can learn from children's worlds of play. Goldman (1998), in his work on pretend play among the Huli in Papua New Guinea, gives us a sense of children taking cultural resources and remaking them. There we see, for example, children's appropriation of the Bi Te storytelling mode and its narrative conventions (1998: 108-109), and the incorporation of ritual fragments into play; pretending to carry a pig on a stick as would be done in a funerary ritual, and chanting the appropriate song (1998: 110-111). Here what is described is a voicing of particular adult roles, almost an apprenticeship in cultural forms. Yet Goldman makes it clear that play is not simply a reproduction of the adult world; it is situated "between mimesis and muthos" (1998: 250). In this way, play is transformative - given forms are taken and shaped afresh. As Katz (2004: 101) suggests of children in Sudan, "The power of the children's play-work was not just that they made sense of their everyday lives and produced themselves in them, but also that the play-work provided a means for making these different"'. This resonates with what Ward (1978: 89) describes when he speaks of play as an adaptation of the imposed environment: "they exploit any feature that the urban landscape happens to provide: end walls for ball games, kerbs, gutters, changes of level... The lifts of the tower block, the trolleys from the supermarket, are incorporated into the repertoire of playthings". The surroundings, defined by concerns which often appear to exclude children's interests, are repurposed and reappropriated.

Narrative imagination plays a key role in this process of shaping the imposed environment afresh. Consider, for example, how Chapel Orchard, a location that we noted above had been deemed "boring" since clearing and tidying work which aimed to make it a 'green space for nature', becomes transformed from a sanitised conservation ground into a 
place of excitement and horror in the story "Death in Chapel Orchard", written by a 10 year old girl at Petersfield school: "One day, James John and Heather fancied a day out to the orchard. They set out on their journey with a picnic. They found a small wooden bench in the centre and they sat down and started eating away. Suddenly Heather heard a strange noise... James felt a cold dark hand touch his shoulder... With a rather large scream, he fell dead to the floor. John and Heather ran super fast trying to escape from whatever got James. Within seconds, John fell to the ground with a large bang from his head. Heather was left there in the deep dark coldness of the orchard, she knew there was no point of running as she was next..."

Anthropomorphism featured in many of the narratives elicited from children. In another story from Petersfield school, one 10 year old boy combined local folklore that we had provided in class as a prompt (accounts of chalk carvings on the South Cambridgeshire Gog Magog hills, and an associated account of a knight who appeared on the hills at the full moon to challenge all comers (Porter 1969: 186-188)) with an understanding of chalk formation in order to tell the tale of "Chris the coccolith". The central protagonist of this story is an anthropomorphic representation of the microscopic unicellular plankton (coccolithophores) whose test consists of calcium carbonate scales (coccoliths); beds of chalk are the result of the accumulation of these coccoliths on the ocean floor over millions of years. "It was a dark and stormy night when Chris the coccolith came to his desition [sic.]. He was fed up of all the coccoliths teasing him for being tiny, as if he wasn't already tiny enough. He stomped out of the hill in a terrible mood and stood as tall as he could (which wasn't very tall at all). He called as loud as he could 'Come out! Come out! Come out and fight!' All the other coccoliths heard him and watched in terror as the dark knight appeared majestically. In a show of bravado he stormed up the knight's armour until he reached the helmet. When he finally tickled the knight's ear the knight screeched like a baby and ran away. From that day forward Chris was a hero." 
Here, a naturalistic understanding of chalk formation (the recognition that chalk consists of the scales of countless numbers of these microscopic organisms) is animated and brought to life in the narrative imagination by an apparent post-hoc anthropomorphism; that is, anthropomorphism is not being used here as a analogistic framework for understanding or naïve theory in the manner described by Hatano and Inagaki (1994), but rather takes materials from what has already been figured out and explained as a naturalistic process and then adds a new layer of mythical meaning. At Bassingbourn School, this anthropomorphic re-reading of the local environment came through when the children were invited to photograph features in the nearby landscape and frequently chose to record features that had human-like characteristics; "We found this tree that looks like a hand; it's just behind the school." These features seeded new stories of their own: "Whose tears filled this hole?"; "Where does this tree walk to every night?” As Nevers et al. (1997) and Gebhard et al. (2003) have argued, anthropomorphism often serves to expand thinking about relationships between humans to a sense of relationship that incorporates plants, animals and ecosystems, and this enables children to frame impacts on non-human entities in moral terms (on the role of anthropomorphism in promoting pro-environmental behaviours see also Bastian et al (2012); Tam et al. (2013)). This sense of narrative imagination as a tool for building a relationship with the environment, we suggest, has a particular importance when we consider that children's experience of exclusion places such relationships under attack.

The social-spatial exclusions of enclosure might appear to negate the possibility of an ethics of proximity in our moral relationships with our environment (Heise 2007); by contrast, many of the strategies adopted by children, such as play and the anthropomorphic imagination, work in an opposite direction, building relationships of proximity with nonhuman entities. Through the life of play and imaginative exploration, children are "enlarging their environment" (Armstrong 1980: 192) and finding ways to rearticulate connections with 
those places from which they are excluded. This does not, of itself, prevent or render irrelevant the exclusions that made such rearticulations necessary in the first place, but it does offer an opportunity to build a relationship that might otherwise be denied, and these relationships offer the opportunity for children to think about the future on their own terms. Indeed, part of our hope in organising these research activities in schools has been to give children a space to assert and express such relationships in the face of environmental transformations that seem beyond their control. The extent to which the children's activities have had an impact on those transformative forces are mixed, as two further examples from our work at Barrington will show.

The first example relates to the work of the 7-9 year olds who worked to propose future uses for the former cement works site. As a result of their projects envisaging the future of the site, and the meetings they had over the course of this work with members of the parish council and employees at the company who owned the cement work site, the children had a direct impact on the plans put forward for development of the site: the inclusion of an area for "unstructured play" (the children actively rejecting the inclusion of a playground in favour of a space that could be used on their own terms). Of course, whether such plans will come to be accepted at all in the context of broader local hostilities to housing development remains to be seen.

The second example relates to work that we were asked to do with younger children at Barrington school, aged 5-7. Having been asked by the teachers to do something that made use of the woodland space behind the school (Queen Elizabeth II woodland, discussed above), we invited the artist Caroline Wendling to work with the children to create art in the woods. The ideas she developed with the children centred on two themes: a maze made from chalk (sourced from the chalk pit), reflecting the underlying geology of the area, and various structures made from wood and string, reflecting the children's fascination with 'den' building 
(on the importance of dens, see Ward 1988: 88-96; Sobel 1993). The children worked to build a whole imaginary townscape in the woods, with structures of their own invention including doorways, windows, shelves, beds, a 'bell' and other musical instruments, an "old fashioned cooker" (a spit), 'zipwires', all the while giving them an opportunity to show us their knowledge of the place: "I saw a muntjac... see, see? I can see its legs"; "I found a woodlouse"; "this is where the older children go to the toilet". The sense of ownership that the children felt from the activities was neatly summarised by one 6 year old girl at the end of a day's activity: "we've made it ours". Yet even as the children worked in the woods, tensions with the parish council became evident. During one day's activities, men working on behalf of the council were fencing off the entry point we had used, pointedly asking us "Can you take them out the proper way please? Where you came in is not a proper entrance." When the time came to return to the classroom, the children were then funnelled out along a path to the 'official' entrance that had been marked out with logs, with the teacher reminding them to “keep along the path". Shortly after the completion of our work in the school, the children's artworks were removed by the council. If the children felt that the work they were doing had 'made it theirs', it was abundantly clear that not everyone agreed with the children's claims to this space.

\section{Beyond enclosure}

In 1821, the English pamphleteer William Cobbett, having been accused of being an enemy of large farms as a consequence of his opposition to tariffs charged on the importation of corn, outlined the circumstances of enclosure under which these large farms had emerged, and excoriated their social effects. "Why, Sir, what a system must that have been that could lead English gentlemen to disregard matters like these! That could induce them to tear up 'wastes' and sweep away occupiers like those that I have described! 'Wastes' indeed! Give a dog an ill name. Was Horton Heath a waste? Was it a 'waste' when a hundred, perhaps, of healthy boys 
and girls were playing there of a Sunday?" (Cobbett 1821: 520-521). Here, he brings to the fore the social effects of enclosure in a way that remains highly pertinent today; and, significantly, highlights impacts on the lives of children that might be obscured by the utilitarian designation of a piece of land as unproductive waste.

The enclosure of land in England between the 16th and 19th centuries has long been understood as a process with enormous social implications (Thirsk 1984; Thompson 1991; Neeson 1993), not only in terms of the deprivation of commoners of their means of livelihood as they lost access to common land, but also as a loss of a relationship between people and their environment. As Thompson (1991: 184) put it, "enclosure, in taking the commons away from the poor, made them strangers in their own land".

It is important not to overstate the experience of loss associated with enclosure for dramatic effect; as Williamson et al. (2013: 160) note, "we must... be careful not to exaggerate or romanticise the freedom offered by the pre-enclosure landscape... there had never been unlimited public rights of access within the unenclosed landscape". Nevertheless, one very significant curtailment was within the lives of children. As Keith Thomas (1983) has argued, enclosure as a process elevated the rational exploitation of the land over and beyond other needs; from the displacement of those living on commons, to the denigration of weeds and the other flora and fauna inhabiting 'waste' (Irvine and Gorji 2013: 127-130). The quote from Cobbett above is provocative precisely because it raises the question of where children's needs are located within this designation of waste. Humphries (1990), in an analysis of late $18^{\text {th }}$ and early $19^{\text {th }}$ century uses of unenclosed land, has argued that women and children were the primary exploiters of commons in England, and that children made an essential contribution to the household through foraging, gleaning, and fuel gathering. The experience of moving within common land was therefore a central part of children's life experience; Humphries (1990: 40) includes the recollections of a girl growing up in 19th century Norfolk, 
who speaks of going with her mother as a young child to gather "all the food that was for free: watercress from running streams, rabbits, pigeons, wild raspberries, wild plums and blackberries, crabapples, hazel nuts, chestnuts, walnuts. No squirrels hoarded these more carefully than we did". In foregrounding the role of children, Humphries makes clear the way in which children's worlds in particular would have been curtailed by enclosure. Here was the space in which children were raised, learned, played, and contributed to the life of the household; and from which they were to find themselves excluded.

With "the systematic elimination... of non-profit-making patches of land" (Ward 1988: 95) in England - exactly those places that children value for play - these curtailments continue apace. Ward offers an important corrective to those who imagine that children growing up in the UK countryside have the luxury of vast swathes of space, and draws our attention to the processes that the children we have described in this paper are all too aware of; land being fenced off, built upon, or otherwise succumbing to the "urge to tidy up everywhere" (1988: 94). Yet such enclosures are not the only dimension of the story; we also see the "ingenuity of children in colonizing odd and temporary spaces for play" (1988: 101). Jeffrey et al. (2012) describe a dialectic of enclosure-commons, suggesting that the proliferation of 'enclosure' needs to be understood through its generative relationship with 'practices of commoning'. Children's relationships with their environment, as discussed in this article, vividly illustrate this not only in the ways they are put under strain by processes of enclosure, but also in how the children actively seek ways of rearticulating those relationships.

Perspectives that speak of 'nature deficit disorder' among children (Louv 2005; Griffiths 2013) are important because they draw attention to what Low (2001), writing in the context of gated communities in the USA, has described as the "fear flight" leading people to seek safe places for their children that are outside of the public sphere. In this way 'public 
space' ceases to be 'child space' (Karsten 2005). As Low notes, such removals, motivated by fear, have a significant impact on how children relate to their environment; we see, for example, increased fear of the city beyond the gates generated by the sense of beleaguered security behind the gates (Low 2001: 54). Yet while such perspectives, emphasising parental concerns and actions, are highly important, we follow Barratt and Barratt Hacking (2008) in suggesting that the extent of children's local knowledge and attachment is often unknown by adults. Such knowledge and attachment emerges from everyday banal encounters (Horton and Kraftl 2006) by which children 'mingle' with their material worlds (Rautio 2014); yet the restrictions of access and movement associated with ongoing processes of enclosure severely disrupt such 'mingling'.

As we have argued, children find little place for themselves within the designation of spaces for development and of spaces for nature; in as much as they experience 'naturedeficit' it is precisely because they find themselves in the midst of a land-use conflict. Such conflicts reveal the ongoing character of enclosure in already-enclosed spaces, particularly in the wake of the encouragement of housing development and a new commodification of the countryside for leisure (Perkins 2006; Crouch 2006). Particularly striking is the sense in which children come to imagine the inevitability of such enclosures - what Hodkinson (2012) describes as the process of subjectification within enclosure, by which a relationship predicated on privatisation and restriction comes to be normalised and accepted.

Yet the rich examples of reappropriation we have found in our East Anglian research suggest that inherence and inclusion in local environments matters to children. Having been excluded from a place that they feel attached to they seek ways of re-appropriating that place; for them inherence in place matters enough to inspire action.

This paper has foregrounded the ways in which children build relationships with and through the materiality of their environment, developing a theme in recent work on children's 
geographies (for example Rautio 2014; Kraftl 2014). We have shown how these material relationships are essential forms of re-articulation in the face of the restrictions which contemporary enclosure brings to children's physical geographies. In doing so, we are adding to the ethnographic understanding of the role of play (Goldman 1998; Katz 2004). Play, which lies at the heart of these relationships, may well be essential for our understanding of the changing world.

Children find themselves particularly exposed to contemporary processes of enclosure, their interests excluded from the sense of what gives land value. Yet what is suggested here is that this is not the end of the story. Children actively seek ways to make such enclosed land 'theirs' again, finding new ways of establishing relationships with the materiality of the land that enclosure's restriction of access denies them, and play and imagination are central to this process.

\section{References}

Ahmed A S, Mynors J B, 1994, "Fowlmere: Roundheads, Rambo and rivalry in an English village today" Anthropology Today 10(5) 3-8

Alderson P, 2001, “Research by children” International Journal of Social Research Methodology 4(2) 139-153

Armstrong M, 1980, Closely Observed Children: The Diary of a Primary Classroom (Writers and Readers, London)

Barratt R, Barratt Hacking E, 2008, “A Clash of Worlds: Children Talking About their Community Experience in Relation to the School Curriculum", in Participation and Learning: Perspectives on Education and the Environment, Health and Sustainability Eds A Reid, B B Jensen, J Nikel, V Simovska (Springer, Dortrecht) pp 285-298 
Bastian B, Costello K, Loughnan S, Hodson G, 2012, "When closing the human-animal divide expands moral concern: the importance of framing", Social Psychological and Personality Science 3(4) 421-429

Bodenhorn B, 1997, “'People who are like our books': Reading and Teaching on the North Slope of Alaska", Arctic Anthropology 34(1) 117-134

Briggs J L, 1991, “Expecting the unexpected: Canadian Inuit training for an experimental lifestyle", Ethos 19(3): 259-287

Brindley T, Rydin Y, Stoker G, 1996, Remaking Planning: The Politics of Urban Change 2nd edition (Routledge, London)

Cahill C, 2007, "Doing Research with Young People: Participatory Research and the Rituals of Collective Work", Children's Geographies 5(3): 297-312

Christensen J H, Mygind L, Bentsen P, 2015, "Conceptions of place: approaching space, children and physical activity”, Children's Geographies 13(5): 589-603

Cloke P, Jones O, 2005, “'Unclaimed territory’: childhood and disordered space(s)”, Social and Cultural Geography 6(3): 311-333

Cobbett W, 1821, “To Mr. Coke: On the question of Large Farms and Small Farms, and on the fall of the System out of which they have arisen" Cobbett's Weekly Register 39(8): 505-566 Colchester M, 1994, Salvaging nature: indigenous peoples, protected areas and biodiversity conservation (United Nations Research Institute for Social Development, Geneva)

Crouch D, 2006, “Tourism, consumption and rurality”, in Handbook of Rural Studies Eds Cloke P, Marsden T, Mooney, P (Sage, London) pp 355-364

Department for Communities and Local Government, 2012, National Planning Policy Framework (Department for Communities and Local Government, London)

Gebhard U, Nevers P, Billmann-Mahecha E, 2003, "Moralizing trees: anthropomorphism and identity in children's relationships to nature", in Identity and the Natural Environment: The 
Psychological Significance of Nature Eds S D Clayton, S Opotow (MIT Press, Cambridge, MA) pp 91-111

Giddings R, Yarwood R, 2005, “Growing up, going out and growing out of the countryside: childhood experiences in Rural England", Children's Geographies 3(1):

Glassman J, 2006, "Primitive accumulation, accumulation by dispossession, accumulation by 'extra-economic' means", Progress in Human Geography 30(5): 608-625

Goldman L R, 1998, Child's Play: Myth, Mimesis and Make-Believe (Berg, Oxford)

Goodway, D, 2006, Anarchist Seeds beneath the Snow: Left-Libertarian Thought and British Writers from William Morris to Colin Ward (Liverpool University Press, Liverpool)

Griffiths, J, 2013, Kith: The Riddle of the Childscape (Hamish Hamilton, London)

Groundwater-Smith S, Dockett S, Bottrell D, 2015, Participatory Research With Children and Young People (Sage, London)

Harris M, Grimshaw A, Ravetz A, Solomons N, Liebheit M, Grasseni C, Walker N, Ward C, Dibb M, 2000, The Child In The City: A Case Study in Experimental Anthropology (Prickly Pear, Manchester)

Harvey D, 2003, The New Imperialism (Oxford University Press, Oxford)

Hatano, G and Inagaki, K, 1994, "Young children's naive theory of biology" Cognition 50(13): $171-188$

Heise U K, 2008, Sense of Place and Sense of Planet: The Environmental Imagination of the Global (Oxford University Press, New York)

Humphries J, 1980, “Enclosures, Common Rights, and Women: The Proletarianization of Families in the Late Eighteenth and Early Nineteenth Centuries" Journal of Economic History 50(1): $17-42$

Hodkinson S, 2012, “The new urban enclosures”, City 16(5): 500-518 
Horton J, Kraftl P, 2006, “Not just growing up, but going on: Materials, Spacings, Bodies, Situations", Children's Geographies 4(3): 259-276

Irvine R D G, 2014, “Deep time: an anthropological problem” Social Anthropology 22(2): $157-172$

Irvine R D G, Gorji M, 2013, "John Clare in the Anthropocene" Cambridge Anthropology 31(1): 119-132

Jeffrey A, McFarlane C, Vasudevan A, 2012, "Rethinking Enclosure: Space, Subjectivity and the Commons", Antipode 44(4): 1247-1267

Jenkins T, 1999, Religion in English Everyday Life: An Ethnographic Approach (Berghahn, Oxford)

Karsten L, 2005, "It All Used to Be Better? Different Generations on Continuity and Change in Urban Children's Daily Use of Space”, Children's Geographies 3(3): 275-290

Katz C, 2004, Growing Up Global: Economic Restructuring and Children's Everyday Lives (University of Minnesota Press, Minneapolis)

Kraftl P, 2014, "Liveability and urban architectures: mol(ecul)ar biopower and the 'becoming lively' of sustainable communities", Environment and Planning D 32(2): 274-292

Louv R, 2005, Last Child in the Woods: Saving our Children from Nature-Deficit Disorder (Algonquin, Chapel Hill, NC)

Low S M, 2001, "The Edge and the Center: Gated Communities and the Discourse of Urban Fear" American Anthropologist 103(1): 45-58

Matthews H, Taylor M, Sherwood K, Tucker F, Limb M, 2000, “Growing-up in the countryside: children and the rural idyll”, Journal of Rural Studies 16(2): 141-153 Mitchell K, Elwood S, 2012, "Mapping children's politics: the promise of articulation and the limits of nonrepresentational theory" Environment and Planning D 30(5): 788-804 
Neeson, J M, 1993, Commoners: Common Right, Enclosure and Social Change in England, 1700-1820 (Cambridge University Press, Cambridge)

Nevers P, Gebhard U, Billman-Mahecha E, 1997, "Patterns of reasoning exhibited by children and adolescents in response to moral dilemmas involving plants, animals and ecosystems" Journal of Moral Education 26(2): 169-186

North D, 1998 “Rural industrialization”, in The Geography of Rural Change Ed Brian Labbery (Routledge, London) pp 161-188

Olwig K F, Gulløv E, 2003, “Towards an anthropology of children and place”, in Children's Places: Cross-cultural perspectives Eds K F Olwig, E Gulløv (Routledge, London) pp 1-19 Perkins H C, 2006, “Comodification: re-resourcing rural areas”, in Handbook of Rural Studies Eds Cloke P, Marsden T, Mooney P (Sage, London) pp 243-257

Philo C, 1992, “Neglected Rural Geographies: a Review”, Journal of Rural Studies 8(2): 193207

Porter E, 1969, Cambridgeshire customs and folklore (Routledge and Kegan Paul, London) Rautio P, 2013, "Children who carry stone in their pockets: on autotelic material practices in everyday life", Children's Geographies 11(4): 394-408

Rautio P, 2014, "Mingling and imitating in producing spaces for knowing and being: Insights from a Finnish study of child-matter intra-action", Childhood 21(4): 461-474

Ryan K W, 2011, "The new wave of childhood studies: Breaking the grip of bio-social dualism", Childhood 19(4): 439-452

Skelton T, 2008, "Research with children and young people: exploring the tensions between ethics, competence and participation”, Children's Geographies 6(1): 21-36

Smith F, Barker J, 2001, "Commodifying the countryside: the impact of out-of-school care on rural landscapes of children's play" Area 33(2): 169-176 
Sobel D, 1993, Children's Special Places: Exploring the Role of Forts, Dens and Bush Houses in Middle Childhood (Zephyr, Tuscon, AZ)

Ssorin-Chaikov N, 2013, "Ethnographic conceptualism: an introduction" Laboratorium 5(2) $5-18$

Strathern, M, 1981, Kinship at the core: an anthropology of Elmdon, a village in north-west Essex in the nineteen-sixties (Cambridge University Press, Cambridge)

Tam K-P, Lee S-L, Chao M M, 2013, “Saving Mr. Nature: anthropomorphism enhances connectedness to and protectiveness toward nature" Journal of Experimental Social Psychology 49(3): 514-521

Thirsk J, 1984, The Rural Economy of England (Hambledon, London)

Thomas K, 1983, Man and the natural world: changing attitudes in England 1500-1800 (Allen Lane, London)

Thomas N, O'Kane C, 1998, "The ethics of participatory research with children" Children and Society 12(5): 336-348

Thompson E P, 1991, Customs in Common (Merlin, London)

Vasudevan A, McFarlane C, Jeffrey A, 2008, "Spaces of enclosure” Geoforum 39(5): 16411646

Tucker F, Matthews H, 2001, “'They Don't like Girls Hanging around There’: Conflicts over Recreational Space in Rural Northamptonshire”, Area 33(2): 161-168

Veale A, 2004, "Creative Methodologies in Participatory Research with Children”, in Researching Children's Experience: Approaches and Methods Eds S Greene, D Hoan (Sage, London) pp 253-272

Waller T, Bitou A, 2011, "Research with children: three challenges for participatory research in early childhood" European Early Childhood Research Journal 19(1): 5-20

Ward C, 1978, The Child in the City (The Architectural Press, London) 
Ward C, 1988, The Child in the Country (Robert Hale, London)

White B, Borras S M, Hall R, Scoones I, Wolford W, 2012, “The new enclosures: critical perspectives on corporate land deals", The Journal of Peasant Studies 39(3-4): 619-647

Williamson T, Liddiard R, Partida T, 2013, Champion: The Making and Unmaking of the English Midland Landscape (Liverpool University Press, Liverpool)

Worpole K, 2014, “On the street where you live: Colin Ward and environmental education”, in Education, Childhood and Anarchism: Talking Colin Ward Eds C Burke, K Jones (Routledge, Abingdon, Oxfordshire) pp 46-53

Woolley H, 2006, "Freedom of the city: Contemporary issues and policy influences on children and young people's use of public open space in England", Children's Geographies $4(1): 45-59$

\section{Acknowledgements}

We would like to thank the students and staff at Petersfield Primary School, Barrington Primary School, and Bassingbourn Primary School for their enthusiastic participation in our research activities and in our September 2014 workshop. Bruce Huett, Libby Peachey, and Hildegard Diemberger worked tirelessly in developing our schools links, and without their assistance and organisation, the work would have been impossible. We are also grateful to Marion Leeper, Caroline Wendling, and John Drayton for their involvement in the activities in the schools.

\section{Funding}

The author(s) disclosed receipt of the following financial support for the research, authorship, and/or publication of this article: The work was supported by a HEFCE Higher Education Innovation Funding (HEIF5) grant 'Gathering and Communicating Climate Knowledge', and 
the AHRC project grant 'Pathways to understanding the changing climate: time and place in cultural learning about the environment' (AH/K006282/1). 